Available online at www.sciencedirect.com

\title{
Shock activation of $\alpha$-alumina from calcinated Al-rich sludge
}

\author{
A.R. Farinha $^{\mathrm{a}, \mathrm{b}}$, J.B. Ribeiro ${ }^{\text {b,* }}$, R. Mendes ${ }^{\mathrm{b}}$, M.T. Vieira ${ }^{\mathrm{a}}$ \\ ${ }^{a}$ CEMUC - Centro de Engenharia Mecânica da Universidade de Coimbra, Department of Mechanical Engineering, University of Coimbra, \\ Rua Luís Reis Santos, Polo II, 3030-788 Coimbra, Portugal \\ ${ }^{\mathrm{b}}$ ADAI - Associação para o Desenvolvimento da Aerodinâmica Industrial, Department of Mechanical Engineering, University of Coimbra, \\ Rua Luís Reis Santos, Polo II, 3030-788 Coimbra, Portugal
}

Received 18 August 2008; received in revised form 9 September 2008; accepted 20 October 2008

\begin{abstract}
Enormous quantities of Al-sludge from aluminum surface treatments are yearly generated all over the world. Despite of being known as important supplier of alumina, the Al-sludge also have some other components that need to be removed. Calcination has revealed to be an inevitable treatment to achieve such objective. It was also found that conventional densification processes are not efficient for this kind of powders and, to overcome that difficulty, a dynamic compaction approach, using detonation generated shock waves have been followed. The calcinated powders compacted by this way have shown up values of density and hardness, after sintering, comparable to the ones of commercial alumina processed by the conventional methods.
\end{abstract}

(C) 2008 Elsevier Ltd and Techna Group S.r.l. All rights reserved.

Keywords: A. Sintering; D. $\mathrm{Al}_{2} \mathrm{O}_{3}$; Explosive compaction; Al-rich industrial sludge

\section{Introduction}

In the last decade research into recycling and valorization of Al-rich sludge's from aluminum surface treatment industries is one of the targets of a scientific community engaged with environmental problems [1-3]. In spite of being considered a nonhazardous waste, the enormous tonnage of this type of sludge produced yearly in the European Community [1], and the difficulties related to its huge volume create problems that improved the cost of its disposal operations. However, due to its high alumina content after calcination [1], several opportunities for its high-tech valorization are being envisaged to form alumina-based materials, like mullite or mullite-alumina products [1-3]. Nevertheless, attempts to recycle calcinated sludge alone are not known, and only rare mixtures of calcinated and as-received sludge have been tested [1,2]. In this case different shape forming methods were tried but the values of the apparent density of the specimens, after sintering, are only slightly above $3300 \mathrm{~kg} / \mathrm{m}^{3}$, which is a consequence of the poor sinterability of this kind of powder mixtures. In spite of all the

\footnotetext{
* Corresponding author. Tel.: +351 239790 700; fax: +351 239790701 .

E-mail address: jose.baranda@dem.uc.pt (J.B. Ribeiro).
}

efforts, references to the absence of interesting applications for this kind of sludge are still being found in recent literature [2] and new processing approaches, like explosive compaction, should be attempted. In fact, being the sintering largely controlled by the morphology and microstructure of the particles, it is expected that variations in those parameters induce significant differences in the sinterability of the powders/compacts. Shock processing of powders, usually described as shock activation, is thought to be capable of such variations due to particle comminution and increase of lattice distortion $[4,5]$.

In the present research, details of the chemical and phase composition of Al-sludge, for two calcination temperatures, have been studied. After explosive compaction, its sinterability has been evaluated by density and microhardness and compared with commercial alumina powders conventionally processed.

\section{Experimental details}

\subsection{Raw materials}

The Al-rich sludge was supplied by Metalfer, Portugal. In order to compare the quality of final products resulting from this sludge, a commercial grade $\alpha$-alumina (BAIKALOX SM8, Baikowski Chimie, France) sub-micrometer-sized powder, 
with median particle size $0.3 \mu \mathrm{m}$ and $99.99 \%$ of purity, was selected as standard material.

The as-received sludge was first heated up to $110{ }^{\circ} \mathrm{C}$ for water evaporation, after which different batches of this dried sludge were calcinated at $1200{ }^{\circ} \mathrm{C}$ and $1650{ }^{\circ} \mathrm{C}$ for a holding time of $1 \mathrm{~h}$ to achieve $\alpha$-alumina as the major phase. Prior to any other use the calcinated powders were milled in an agate mortar and sieved cut at $100 \mu \mathrm{m}$. The as-received and calcinated sludge were characterized according to the particle size by laser diffraction spectrometry (LS130, Coulter Corporation), from powder suspension in water, with a Fraunhofer apparatus, and according to density by Helium Picnometry (Accupy 1330, Micromeritics Instrument Corporation). The particles shape and microstructure were characterized using scanning electron microscope (JSM5310, JEOL), and the phase evolution with calcination temperature by X-ray diffraction (X-Pert Phillips) using a Bragg-Brentano configuration and $\operatorname{Co}(\mathrm{K} \alpha)$ radiation. The chemical composition of the heat treated sludge was characterized by wavelength-dispersive X-ray fluorescence spectrometry (XRF) (PW2404, PANanalytical) and finally, the thermal behavior of the dried sludge was analyzed by differential scanning calorimetry and thermogravimetry (DSC/TG) (STA 1500, Rheometric Scientific Limited) for a temperature range from $30{ }^{\circ} \mathrm{C}$ to $1450{ }^{\circ} \mathrm{C}$ and a heating rate of $10{ }^{\circ} \mathrm{C} / \mathrm{min}$.

\subsection{Compaction tests}

The explosive compaction tests were carried out using the simplest and well-known direct method, the so-called cylindrical configuration [6-9] (Fig. 1(a)). In this arrangement a steel tube containing the powders, and closed at both ends, is surrounded by a explosive composition. When detonated from upwards, a ringshaped detonation front advances in the axial direction, driving the container wall inward and originating a shock wave which proceeds into the powder leading to densification. Dimensional details of the set-up used in this work are presented in Fig. 1(b). The powder container was filled batch-wise by pouring small amounts of the powder into the steel tube that was also uniaxially compressed. The mass of the tube and of the powder was then measured and the density of the green sample evaluated.

Ammonium nitrate-based water-in-oil emulsion, provided by SEC-Sociedade de Explosivos Civis, Aljustrel, Portugal, sensitized with different amounts of hollow perlite microspheres was used as explosive composition. Since the detonation velocity of this explosive composition is mainly dependent on the density [10] and once the detonation velocity is thought to be one of the most important process parameters, for each experiment its density was evaluated by gravimetric methods.

Explosive compaction experiments were carried out with calcinated $\left(1200^{\circ} \mathrm{C}\right.$ and $\left.1650^{\circ} \mathrm{C}\right)$ sludge and standard alumina for two different detonation velocities. After being explosively compacted the specimens were slice cut, characterized and kept for subsequent sintering. Densification of the explosively compacted specimens was evaluated by the Archimedes method using water, while microhardness (Micro Hardness Tester HMV-2, Shimadzu Corporation) was measured using a Vickers diamond indenter with a $2.94 \mathrm{~N}$ load and an indentation time of $15 \mathrm{~s}$. Morphology characterization was performed using the same technique and equipment as for the sludge.

\subsection{Sinterization tests}

Sintering of explosively compacted samples was carried out for dwell times of $1 \mathrm{~h}$ or $4 \mathrm{~h}$ at a temperature of $1650{ }^{\circ} \mathrm{C}$. Uniaxially Pressed $(70 \mathrm{MPa})$ and Cold Isostatic Pressed (200 MPa, National Forge Europe, Pressure Systems N.V.) samples of calcinated $\left(1650{ }^{\circ} \mathrm{C}\right)$ sludge and standard alumina were also sintered in the same conditions as the explosive
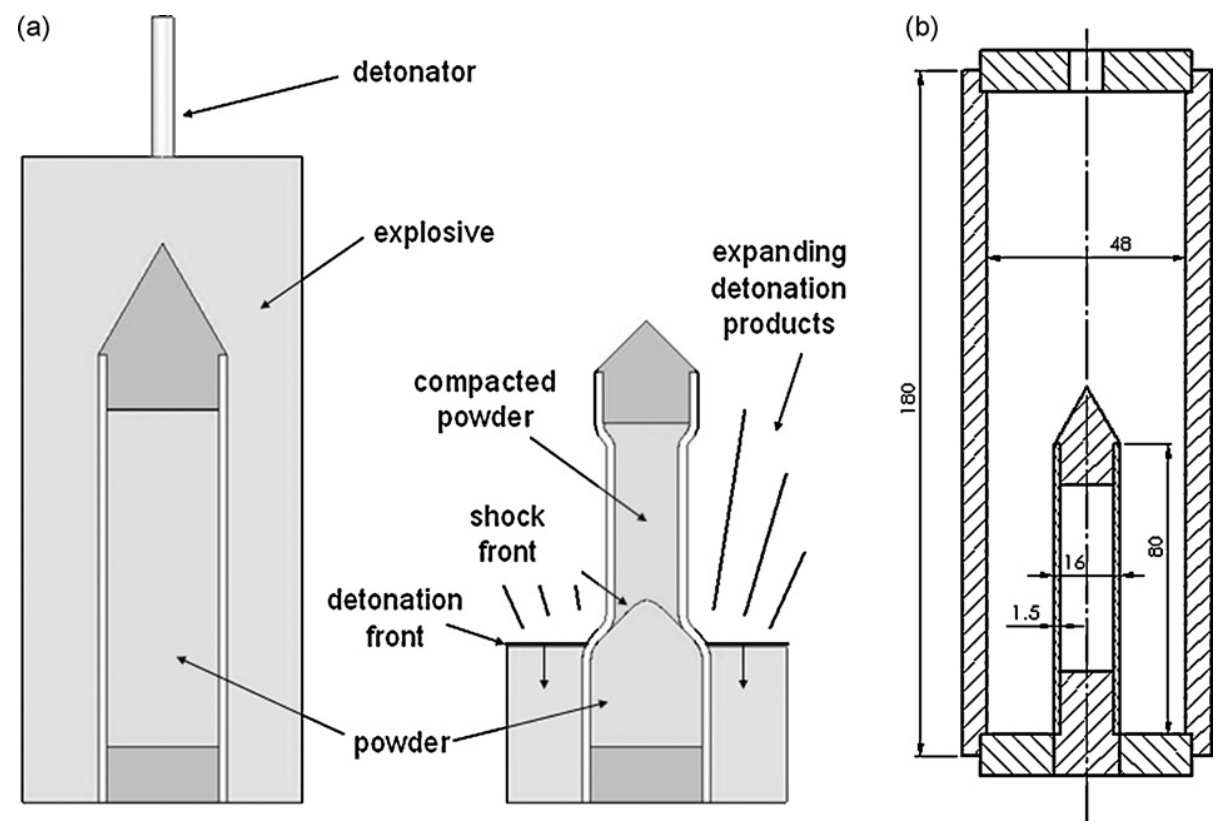

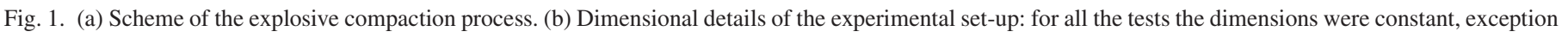
for the diameter of the explosive container that was 40,48 or $62 \mathrm{~mm}$. 


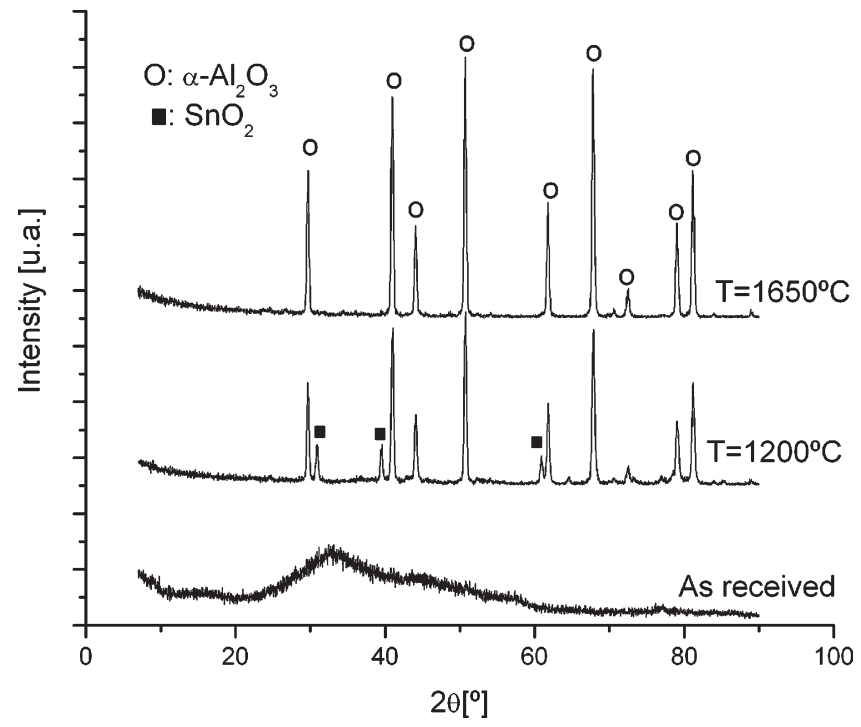

Fig. 2. X-ray diffraction, at different temperatures, of the as-received and calcinated sludge.

compacted ones. Sintered samples were characterized concerning to densification, microhardness and morphology using the same methodology as for the compacted ones.

\section{Results}

\subsection{Sludge characterization}

The light grey colored as-received sludge was found to be amorphous as can be detected in the XRD diffractogram (Fig. 2). The initial water content was close to $85 \%$, while the density and the mean particle size were evaluated as being $1136 \mathrm{~kg} / \mathrm{m}^{3}$ and $14.2 \mu \mathrm{m}$, respectively. For the $1200{ }^{\circ} \mathrm{C}$

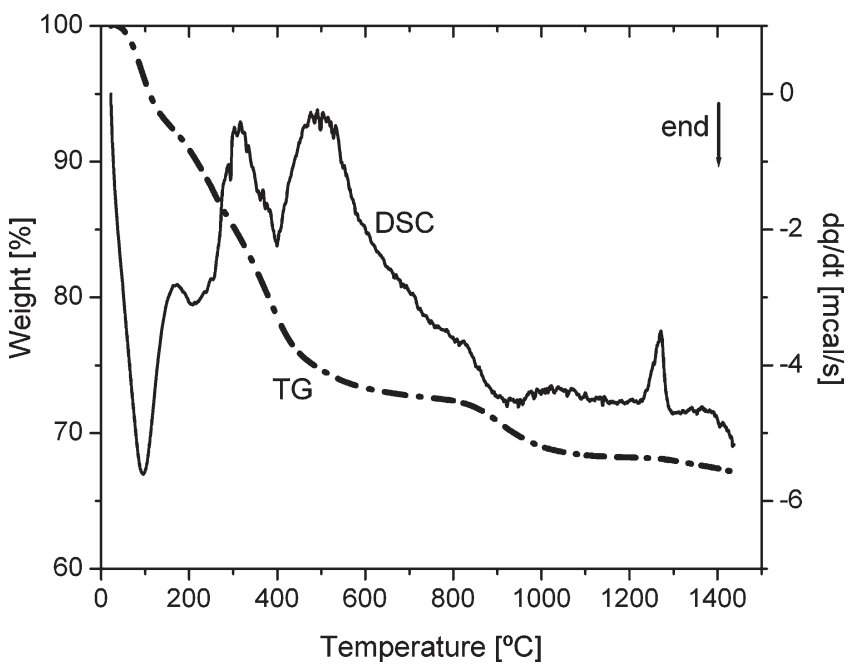

Fig. 4. DSC/TG curves of dried $\left(110^{\circ} \mathrm{C}\right)$ sludge.

calcinated sludge the XDR pattern (Fig. 2) reveals the formation of $\alpha$-alumina and the presence of traces of tin oxide from the anodizing bath. The morphology of these particles was lamellar as observed in Fig. 3(a), being the density and mean particle size $3871 \mathrm{~kg} / \mathrm{m}^{3}$ and $9.71 \mu \mathrm{m}$, respectively. At $1650{ }^{\circ} \mathrm{C}$, according to the XRD, the tin oxide peaks disappeared and the powder was essentially $\alpha$-alumina. The density and the mean particle size were found to be $3905 \mathrm{~kg} / \mathrm{m}^{3}$ and $90.75 \mu \mathrm{m}$, respectively. At this temperature, the initial individual lamellar particles change to large agglomerates due to coalescence (Fig. 3(b)).

The chemical composition of the calcinated sludge is shown in Table 1. It is important to point out that if on one hand there is a significant amount of oxide impurities in both powders, on the other, the amount of contaminants is reduced by one half when the calcination temperature increases from $1200{ }^{\circ} \mathrm{C}$ to $1650{ }^{\circ} \mathrm{C}$. (a)

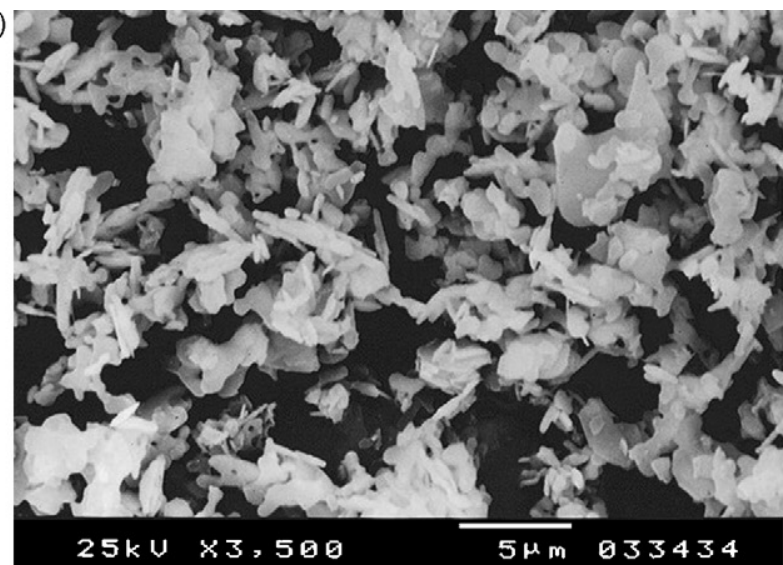

(b)

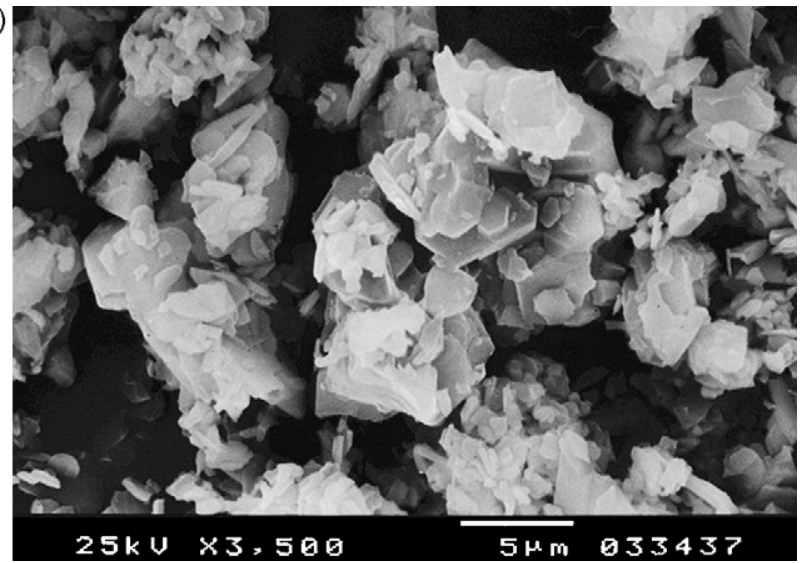

Fig. 3. SEM micrographs of the calcinated sludge: $1200{ }^{\circ} \mathrm{C}$ (a) and $1650{ }^{\circ} \mathrm{C}$ (b).

Table 1

Chemical composition (wt.\%) and loss on ignition at $1150{ }^{\circ} \mathrm{C}$ (LOI) of calcinated sludge.

\begin{tabular}{|c|c|c|c|c|c|c|c|c|c|c|c|c|}
\hline Temperature $\left({ }^{\circ} \mathrm{C}\right)$ & $\mathrm{Al}_{2} \mathrm{O}_{3}$ & $\mathrm{SnO}_{2}$ & $\mathrm{Na}_{2} \mathrm{O}$ & $\mathrm{SiO}_{2}$ & $\mathrm{P}_{2} \mathrm{O}_{5}$ & $\mathrm{MgO}$ & $\mathrm{Fe}_{2} \mathrm{O}_{3}$ & $\mathrm{CaO}$ & $\mathrm{K}_{2} \mathrm{O}$ & $\mathrm{MnO}$ & $\mathrm{TiO}_{2}$ & LOI \\
\hline 1200 & 91.94 & 1.8 & 1.78 & 1.67 & 1.23 & 0.81 & 0.56 & 0.48 & 0.06 & 0.02 & $<0.04$ & 0.32 \\
\hline 1650 & 95.11 & 0.85 & 0.91 & 1.41 & 0.68 & 0.65 & 0.56 & 0.34 & $<0.03$ & $<0.02$ & $<0.04$ & 0.05 \\
\hline
\end{tabular}


Table 2

Explosive compaction process parameters and results ( $D$ —detonation velocity and TMD—-theoretical maximum density).

\begin{tabular}{|c|c|c|c|c|c|c|}
\hline \multirow[t]{2}{*}{ Sample } & \multirow[t]{2}{*}{$T_{\text {calcination }}\left({ }^{\circ} \mathrm{C}\right)$} & \multirow[t]{2}{*}{$D(\mathrm{~mm} / \mu \mathrm{s})$} & \multicolumn{2}{|c|}{ Initial density } & \multicolumn{2}{|c|}{ Final density } \\
\hline & & & $\left(\mathrm{g} / \mathrm{cm}^{3}\right)$ & $\overline{(\% \mathrm{TMD})}$ & $\left(\mathrm{g} / \mathrm{cm}^{3}\right)$ & $\overline{(\% \mathrm{TMD})}$ \\
\hline M.12.1 & 1200 & 3.7 & 1.97 & 50.8 & 3.00 & 77.9 \\
\hline M.12.2 & 1200 & 4.4 & 2.17 & 56.0 & 3.50 & 90.4 \\
\hline M.16.1 & 1650 & 3.5 & 2.85 & 72.9 & 3.45 & 88.3 \\
\hline M.16.2 & 1650 & 4.4 & 2.85 & 72.9 & 3.64 & 93.2 \\
\hline Al.1 & n.a. & 3.5 & 2.30 & 57.4 & 3.00 & 74.7 \\
\hline Al. 2 & n.a. & 4.5 & 2.38 & 59.2 & 3.25 & 81.1 \\
\hline
\end{tabular}

The DSC/TG results for the dried sludge (Fig. 4) show a first endothermic transformation close to $100{ }^{\circ} \mathrm{C}$, that is consequence of a decrease in the water content, either not evaporated during the drying at $110{ }^{\circ} \mathrm{C}$ or adsorbed onto the surface after the drying process; the weight loss was $5 \%$. Between $175^{\circ} \mathrm{C}$ and $250{ }^{\circ} \mathrm{C}$, a second endothermic transformation, that can be associated with the transition of gibsite
$\left(\mathrm{Al}(\mathrm{OH})_{3}\right)$ into bohemite $(\mathrm{AlO}(\mathrm{OH}))$ is observed. From $320{ }^{\circ} \mathrm{C}$ to $470{ }^{\circ} \mathrm{C}$, a third endothermic transformation, now associated with the transition of bohemite into $\gamma$-alumina, is detected. The total weight loss for these two transformations is estimated in $13 \%$. Sulphates decomposition, mainly of sodium sulphate and aluminum sulphate, occurs just before $1000{ }^{\circ} \mathrm{C}$, in accordance with the small endothermic peak and
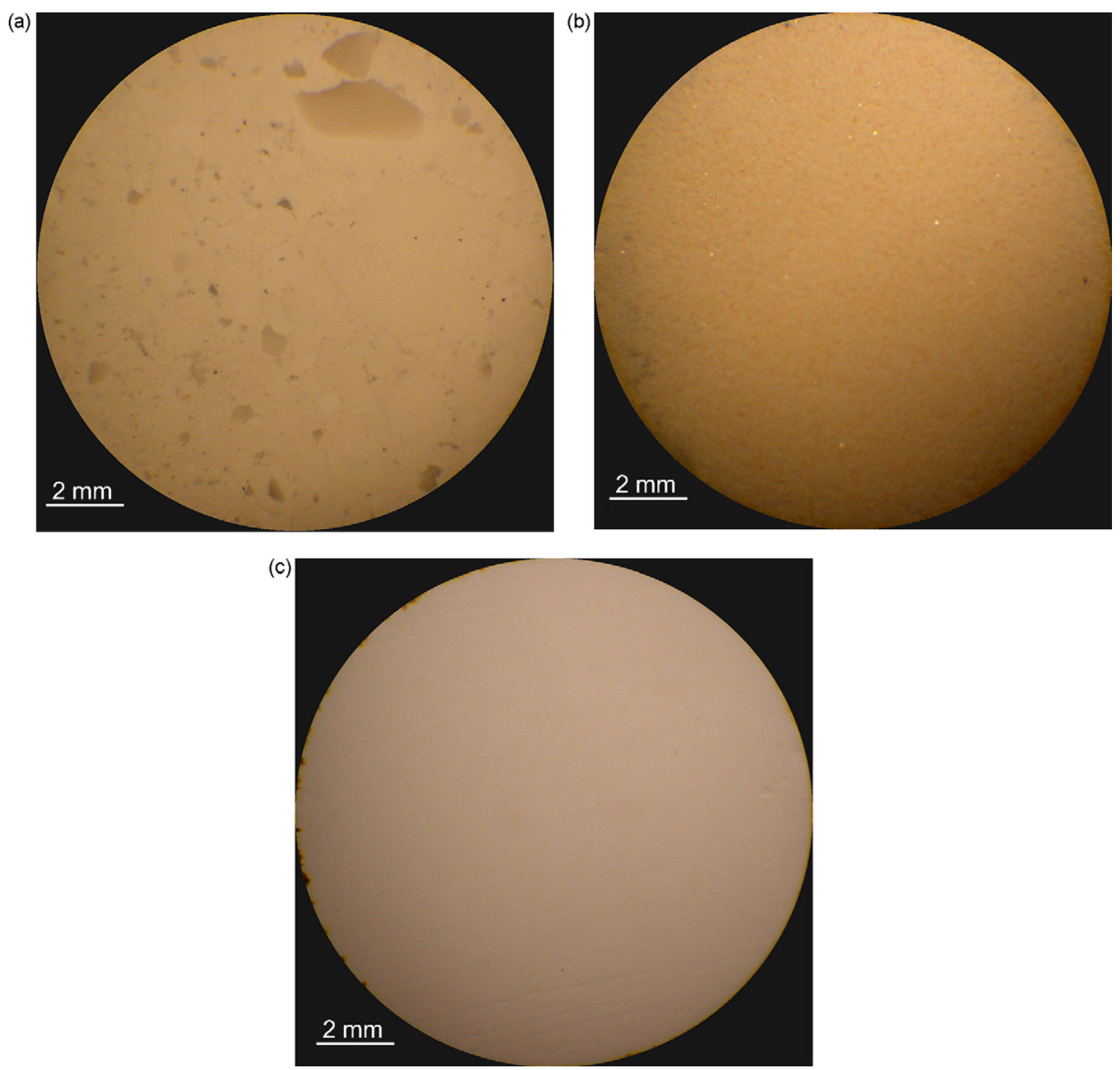

Fig. 5. Compacted samples photography: (a) $1200{ }^{\circ} \mathrm{C}$ calcinated sludge (M.12.1), (b) $1650{ }^{\circ} \mathrm{C}$ calcinated sludge (M.16.2) and (c) commercial grade alumina (Al.1).

Please cite this article in press as: A.R. Farinha, et al., Shock activation of $\alpha$-alumina from calcinated Al-rich sludge, Ceram. Int. (2008), doi:10.1016/j.ceramint.2008.10.031 
a $10 \%$ weight loss at that temperature. Finally, the transformation from $\gamma$-alumina into $\alpha$-alumina is observed as a clear exothermic peak in temperature range from $1200{ }^{\circ} \mathrm{C}$ to $1300{ }^{\circ} \mathrm{C}$.

\subsection{Compaction tests}

The explosive compaction experiments were performed under the conditions described above for sludge previously calcinated at $1200{ }^{\circ} \mathrm{C}$ and $1650{ }^{\circ} \mathrm{C}$ and for commercial grade $\alpha$ alumina. The values of the process parameters used in each test, as well as the initial and final density of the compacted specimens are summarized in Table 2. The maximum values of the final density are attained for the experiments performed with the explosive compositions showing the greatest detonation velocity. Nevertheless, those maximum values are higher for the sludge, either calcinated at $1200{ }^{\circ} \mathrm{C}$ or $1650{ }^{\circ} \mathrm{C}$, than for the commercial grade alumina. It is also important to point out for the significant differences observed for the values of the initial densities of powders within the steel container, prior to explosive compaction. It should be said that those values were the highest that could be attained during the sample preparation for each one of the tested powders.

The microstructures of circular slice-shaped samples of selected experiments are shown in Fig. 5. It is important to notice that all the samples are virtually crack free showing a great homogeneity throughout the entire cross-section. SEM images of the fracture surfaces of the same specimens are shown in Fig. 6. While for the $1200{ }^{\circ} \mathrm{C}$ calcinated sludge and for the commercial grade alumina samples the fracture surface is intergranular, for the $1650{ }^{\circ} \mathrm{C}$ calcinated sludge the fracture is transgranular.

\subsection{Sintering tests}

The first point to be emphasized is the disaggregation of the compacts prepared from $1200{ }^{\circ} \mathrm{C}$ calcinated sludge after being fired at $1650{ }^{\circ} \mathrm{C}$ for $1 \mathrm{~h}$. Thus, it was impossible to evaluate their density and microhardness and no further dwell times were considered. All the other sintered samples, from commercial grade alumina or $1650{ }^{\circ} \mathrm{C}$ calcinated sludge, either static (uniaxial or isostatic) or explosively compacted, reveal an increase in density and microhardness after the sintering process (Table 3 ). However, the differences in those properties are much more important for the commercial grade alumina than for the sludge. In the first case it was also found that the considerable difference in the initial density between the uniaxial and explosive compacted specimens led to an insignificant difference in the density after sintering. Nevertheless, significant differences in the microhardness of those specimens were measured. Their micrographs (SEM) (Fig. 7) show that the initial particles are still perceptible for the uniaxial pressed specimens but not for the explosively compacted ones. In this last case, the boundaries/disconti-
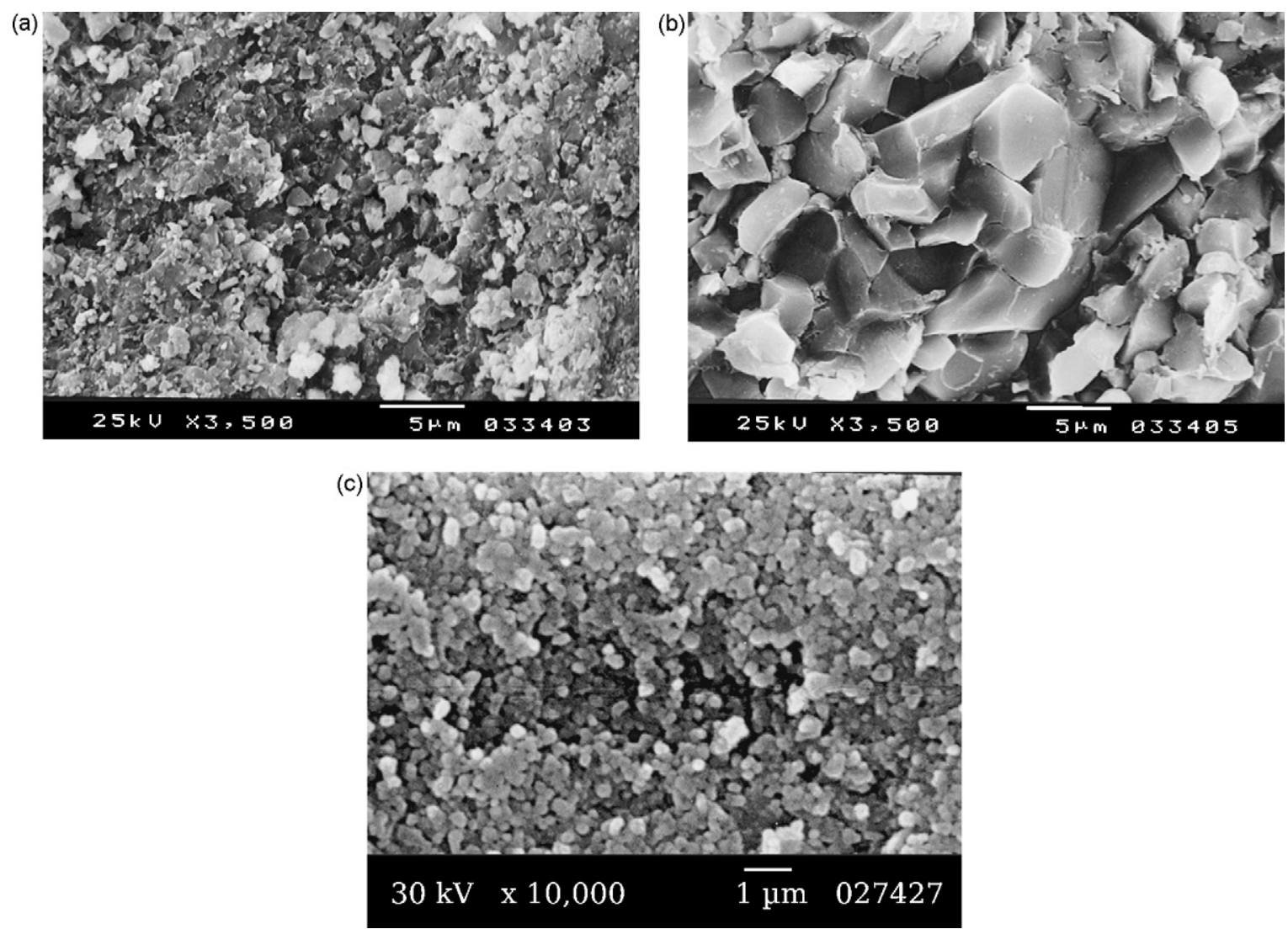

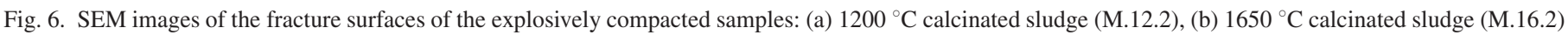
and (c) commercial grade alumina (Al.2). 
Table 3

Sintering process parameters and results.

\begin{tabular}{|c|c|c|c|c|c|c|c|}
\hline \multirow[t]{3}{*}{ Compaction method } & \multirow[t]{3}{*}{ Initial density (\% TMD) } & \multicolumn{3}{|l|}{$t=1 \mathrm{~h}$} & \multicolumn{3}{|l|}{$t=4 \mathrm{~h}$} \\
\hline & & \multicolumn{2}{|l|}{ Density } & \multirow[t]{2}{*}{ Hardness (GPa) } & \multicolumn{2}{|l|}{ Density } & \multirow[t]{2}{*}{ Hardness (GPa) } \\
\hline & & $\left(\mathrm{g} / \mathrm{cm}^{3}\right)$ & $\overline{(\% \mathrm{TMD})}$ & & $\left(\mathrm{g} / \mathrm{cm}^{3}\right)$ & $\overline{(\% \mathrm{TMD})}$ & \\
\hline \multicolumn{8}{|l|}{ Alumina } \\
\hline Uniaxial & 57.4 & 3.90 & 97.2 & $11.2 \pm 1.3$ & 3.93 & 98.0 & $13.0 \pm 0.9$ \\
\hline Explosive & 74.7 & 3.91 & 97.5 & $17.4 \pm 1.3$ & 3.93 & 98.0 & $20.2 \pm 2.1$ \\
\hline Explosive & 81.1 & 3.90 & 97.0 & $17.9 \pm 1.5$ & 3.92 & 97.8 & $17.9 \pm 0.8$ \\
\hline \multicolumn{8}{|l|}{ Sludge $1650{ }^{\circ} \mathrm{C}$} \\
\hline Uniaxial & 72.9 & 3.19 & 81.7 & a & 3.37 & 86.3 & a \\
\hline CIP & 72.9 & 3.23 & 82.7 & a & 3.35 & 85.8 & a \\
\hline Explosive & 88.3 & 3.69 & 94.4 & $7.9 \pm 1.3$ & 3.75 & 96.0 & $8.5 \pm 1.4$ \\
\hline Explosive & 93.2 & 3.73 & 95.4 & $12.0 \pm 1.5$ & 3.77 & 96.5 & $15.0 \pm 1.6$ \\
\hline
\end{tabular}

a Impossible to evaluate.

nuities define sintered regions bigger than the initial particles.

For the uniaxial or isostatic pressed sludge it was impossible to assess the microhardness values due to the low green density. However, their density was found to increase with the dwell time during sintering. For the explosively compacted sludge the density, after sintering, was found to be higher than what was reported in the literature for the same material compacted with traditional techniques [1,2]. The microhardness of this sludge was found similar to that of the commercial grade alumina processed by the same way.

SEM images of fracture surfaces of the sintered sludge uniaxial and explosive compacted specimens are shown in Fig. 8. The differences are clearly visible and in accordance with the measured values of density. It is possible to notice longitudinal (intragranular porosity) crack-shaped pores in the uniaxially pressed material. For the explosive compacted one, the pores are almost inexistent. It is also important to highlight (a)

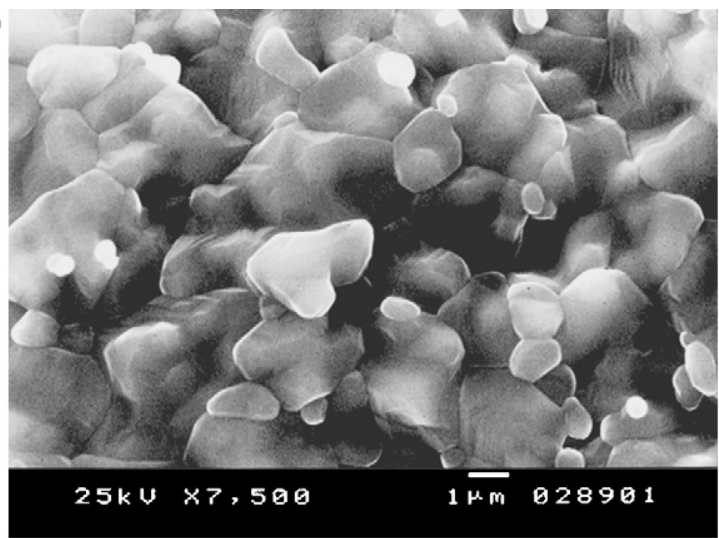

(c) "

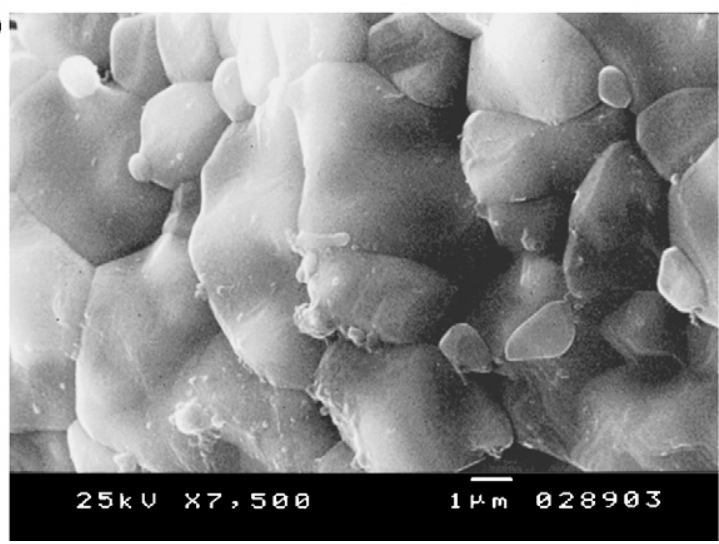

(b)

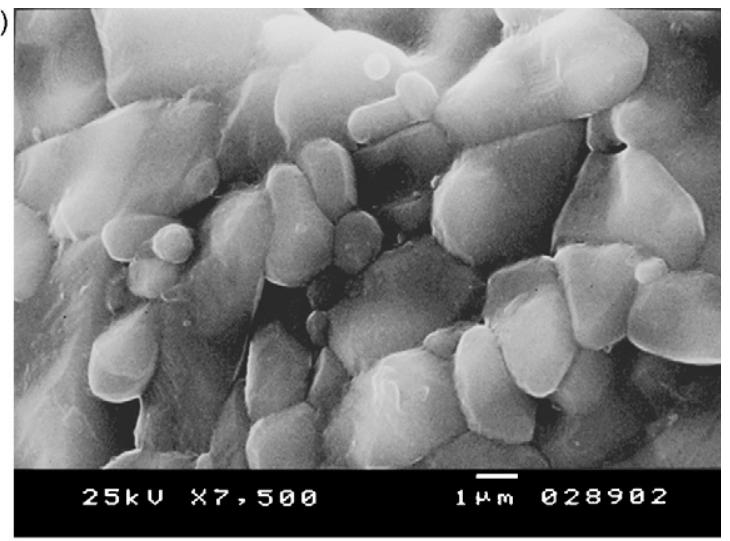

(d) |

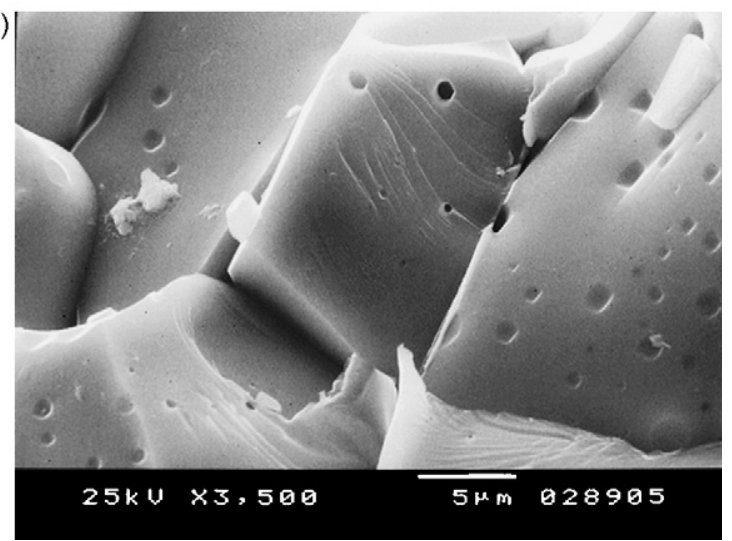

Fig. 7. SEM images of the fracture surfaces of commercial grade alumina: (a) uniaxial compacted and sintered (1 h), (b) uniaxial pressed and sintered (4 h), (c) explosive compacted and sintered (1 h) and (d) explosive compacted and sintered (4 h).

Please cite this article in press as: A.R. Farinha, et al., Shock activation of $\alpha$-alumina from calcinated Al-rich sludge, Ceram. Int. (2008), doi:10.1016/j.ceramint.2008.10.031 
(a)

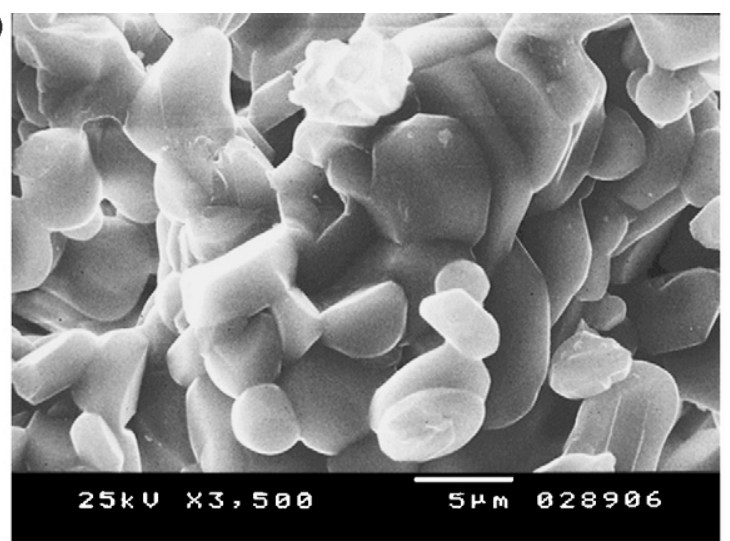

(c)

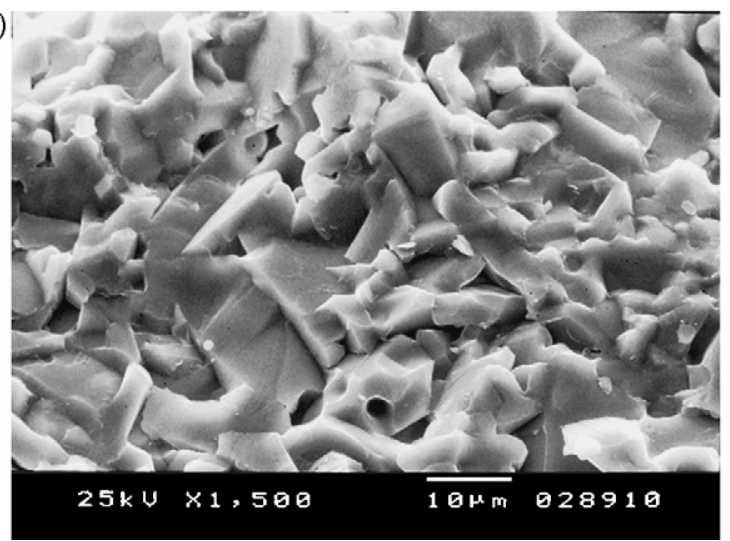

(b)

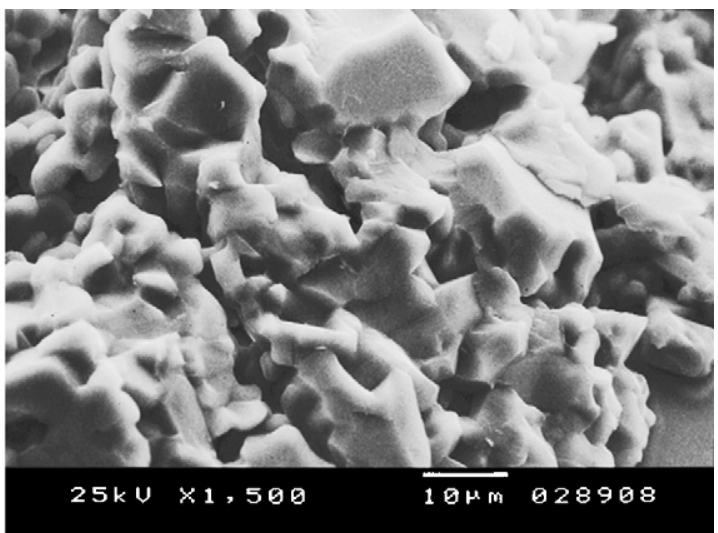

(d)

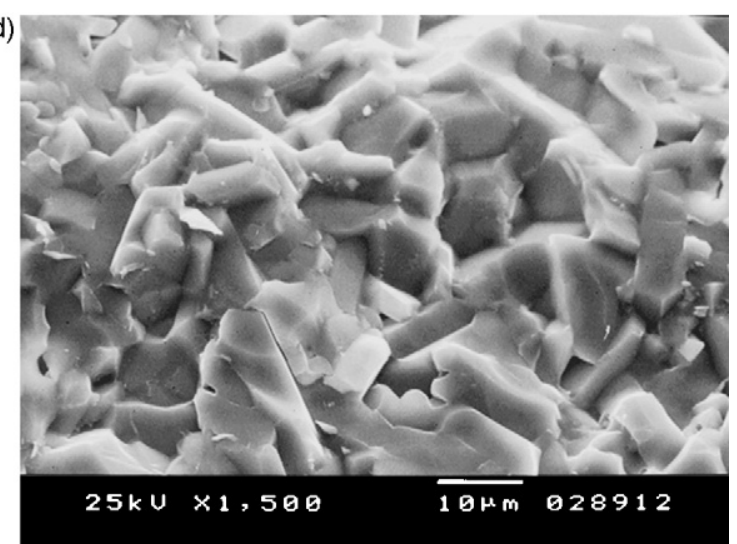

Fig. 8. SEM images of the fracture surfaces of $1650^{\circ} \mathrm{C}$ calcinated sludge: (a) uniaxial compacted and sintered ( $\left.1 \mathrm{~h}\right)$, (b) uniaxial compacted and sintered ( $\left.4 \mathrm{~h}\right)$, (c) explosive compacted and sintered $(1 \mathrm{~h})$ and $(\mathrm{d})$ explosive compacted and sintered $(4 \mathrm{~h})$.

that the fracture surface for the uniaxial pressed alumina is intergranular, along the surfaces of the agglomerates resulting from calcination. The fracture surface of the explosive compacted alumina appears to be transgranular, which can be considered as a signal of significant consolidation.

\section{Discussion}

\subsection{Sludge characterization}

After the calcination at $1200{ }^{\circ} \mathrm{C}$, the formation of $\alpha$-alumina, is in accordance with the increase in the density up to values similar to the ones of $\alpha$-alumina. It should be underlined that while the DSC analysis point for a $\gamma$-alumina to $\alpha$-alumina phase transformation occurring above $1200{ }^{\circ} \mathrm{C}$, in the XRD diffractogram of the same sludge, at $1200{ }^{\circ} \mathrm{C}$, no $\gamma$-alumina was detected. This fact is related with the differences in the transformation kinetics that are expected to exist between isothermal (calcination) and anisothermal (DSC/TG) processes.

\subsection{Compaction experiments}

One of the most surprising results concerns the abnormally high initial density of the $1650{ }^{\circ} \mathrm{C}$ calcinated samples prior to explosive compaction (just uniaxially pressed). Such results can only be explained by the enlargement of the size distribution of the heat treated particles.
The densification of the explosive compacted powders is thought to be a consequence of a three stage sequential process [11]. In the first stage, compaction takes place due to the particle rearrangement, at relatively low pressures, occurring at the shock front for a thickness of a few particles. A significant densification, without deformation, is believed to occur at this stage with no relevant heating. In the second stage significant heating is generated in the outer shell of the particles, due to the friction and/or strong localized deformations depending on the material properties. Finally, in the last stage, densification occurs through the particle bulk deformation or/and fracture. Thus, the differences between the final densities of the explosive compacted specimens can be explained based on the existence of significant differences in the extension of the compacts in the last stage. For low detonation velocities, the shock wave pressure is not enough to fracture the particles and the compaction is then restricted to the first stage. This conclusion is in accordance with the differences in the characteristic particle size that can be inferred from the comparison of SEM images of the sludge explosively compacted with compositions presenting different detonation velocities; the higher detonation velocity lead to the smallest particle sizes. For the commercial grade alumina this effect is not so evident due to the spherical shape of the particles.

The absence of macro-cracks, whatever the sample's processing conditions, must be highlighted. This uncommon behavior is due to the modest variation of the initial volume of 
the powders, as in the $1650{ }^{\circ} \mathrm{C}$ calcinated sludge and the commercial grade alumina or in the existence of a very extensive particle rearrangement and fractures stages without significant consolidation, as for the $1200{ }^{\circ} \mathrm{C}$ calcinated sludge.

As regards to the reported differences in the SEM images, it appears clear that for any of the performed experiments with the commercial grade alumina, the explosively generated shock wave was not enough to produce a significant consolidation. Moreover, for this particular material the process induces a small densification. Thus, it is not surprising that the compacted material show intergranular fracture surfaces. For the sludge calcinated at $1200{ }^{\circ} \mathrm{C}$, despite the notable densification observed for the experiment performed with the higher detonation velocity explosive composition, the fracture surface is intergranular, meaning a poor consolidation. However, for the sludge calcinated at $1650{ }^{\circ} \mathrm{C}$, a transgranular fracture is shown in the SEM images. Nevertheless, due to the moderate densifications, and taking into account what was observed for the $1200{ }^{\circ} \mathrm{C}$ calcinated sludge samples, is unlikely that the heat generation during the compaction process could be enough to promote consolidation up to levels justifying such fracture mode. The origin of those transgranular cracks must be attributed to fracture of the initial particle agglomerates.

\subsection{Sintering experiments}

The explanation for the disaggregation of the $1200{ }^{\circ} \mathrm{C}$ calcinated sludge samples, during sintering at $1650{ }^{\circ} \mathrm{C}$, is related to the release of some of the impurities still existing in the sludge. According to the chemical characterization, a variation of the calcination temperature from $1200{ }^{\circ} \mathrm{C}$ to $1650{ }^{\circ} \mathrm{C}$, results in about $3.2 \%$ mass loss, which can clearly justify its disaggregation when sintered at $1650{ }^{\circ} \mathrm{C}$.

Kim et al. [5] reported that the significant differences in the initial density found for alumina specimens compacted by different ways, have effects only in the early stages of the densification process. However, in the present study, those consequences are still perceptible in the final density and consequently in the hardness. For the alumina sintered during $1 \mathrm{~h}$, after uniaxial or explosive compaction, the grains links appear to be weak so that the fracture surfaces are clearly intergranular. For the alumina sintered during $4 \mathrm{~h}$, however, a considerable increase of the grain links strength for the explosively compacted samples, reflected on a transgranular fracture surface and an increase of the microhardness values, is observed.

With regard to the sludge, despite some densification, it seems evident from the SEM images of the surfaces of the uniaxial or isostatically pressed specimens that there is no significant sintering beyond the initial bonding of the sludge particles during the calcination. However, the explosive compacted powders, after sintering, reached values of density and microhardness comparables to the ones of commercial alumina. This enhanced sinterability, due to the increase of lattice distortion, is in accordance with what has been referred by several authors [4,5].

\section{Conclusion}

For the particular case of the sludge studied the $\alpha$-alumina is the main phase presented after calcination at temperatures about $1200{ }^{\circ} \mathrm{C}$. However, in order to avoid problems during the sintering process, due to the release of contaminants, it is necessary to calcinate them up to $1650{ }^{\circ} \mathrm{C}$. This heat treatment induces an agglomeration of the sludge particles, a reduction of their specific surface area, and a significant reduction of their sinterability, at least when compared with commercial $\alpha$ alumina particles. Nevertheless, explosive compaction of this calcinated sludge led to very high compaction densities and a reversion in the reduction of the sinterability of the sludge particles. After sintering, the density and microhardness are similar to those of commercial alumina.

\section{Acknowledgements}

The authors are indebt to the Portuguese Foundation for Science and Technology for funding this work under contract POCI/EME/55398/2004, to SEC (Sociedade de Explosivos Civis, S.A.), Aljustrel, Portugal, for kindly providing the AN emulsion matrix and to Metalfer-Metalúrgica de Fermentelos, S.A. Águeda, Portugal.

\section{References}

[1] M.J. Ribeiro, J.C. Abrantes, J.M. Ferreira, J.A. Labrincha, Recycling of Alrich industrial sludge in refractory ceramic pressed bodies, Ceramics International 28 (3) (2002) 319-326.

[2] M.J. Ribeiro, D.U. Tulyaganov, J.M. Ferreira, J.A. Labrincha, Production of Al-rich sludge-containing ceramic bodies by different shaping techniques, Journal of Materials Processing Technology 148 (1) (2004) 139_ 146.

[3] S.C. Vieira, A.S. Ramos, M.T. Vieira, Mullitization kinetics from silicaand alumina-rich wastes, Ceramics International 33 (1) (2007) 59-66.

[4] R.A. Graham, Solids Under High-pressure Shock Compression, SpringerVerlag, USA, 1992.

[5] K.Y. Kim, Y. Horie, A.D. Batchelor, H. Kanda, M. Akaishi, O. Fukunaga, Effects of dynamic vs. static compaction on the sinterability of alumina powders, in: Shock Waves in Condensed Matter-1983, Proceedings of the American Physical Society Topical Conference on Shock Waves in Condensed Matter, 1983.

[6] R.A. Pruemmer, T.B. Bhat, K.S. Kumar, K. Hokamoto, Explosive Compaction of Powders and Composites, Science Publisher, USA, 2006.

[7] R.A. Pruemmer, P. Weimar, Explosive consolidation of nanopowders, Interceram 51 (6) (2002) 394-398.

[8] J.B. Ribeiro, R.L. Mendes, I. Ye Plaksin, J.A. Campos, Features of the shock and detonation waves in cylindrical explosive compaction, in: Shock Compression of Condensed Matter-2005, Proceedings of the Conference of the American Physical Society Topical Group on Shock Compression of Condensed Matter, 2006, pp. 1161-1164.

[9] I. Plaksin, J. Campos, J. Ribeiro, R. Mendes, J. Direito, D. Braga, R. Pruemmer, Novelties in physics of explosive welding and powder compaction, Journal de Physique IV 110 (2003) 797-802.

[10] R. Mendes, J. Ribeiro, I. Plaksin, J. Campos, Detonation wave characterization of aluminized and non-aluminized emulsion explosives, in: Proceedings of the 37th International Annual Conference of ICT: Energetic Materials-Insensitivity, Ageing, Monitoring, 2006, pp. V15-1-V15-11.

[11] E.P. Carton, Shock Compaction of Ceramics and Composites, Delft University, Netherland, 1997. 